\title{
Facile Synthesis of Efficient Cu-Co-Fe Ternary Oxides by Pulsed-spray Evaporation CVD for CO Oxidation
}

\author{
Muhammad Waqas, ${ }^{1,2}$ Patrick Mountapmbeme Kouotou, ${ }^{1,3}$ Achraf El Kasmi, ${ }^{1}$ Yu Wang, ${ }^{4}$ and Zhen-Yu Tian ${ }^{1,2,}$
}

Thin film of Cu-Co-Fe ternary oxides was prepared by pulsed-spray evaporation chemical vapor deposition (PSE-CVD) for catalytic combustion of CO. The physicochemical properties of as-prepared ternary oxides were comprehensively characterized by SEM, EDS, XPS, XRD and UV-vis spectroscopy techniques. The catalytic performance of the ternary oxides was examined in a fixed-bed reactor with gas hourly space velocity (GHSV) of $75,000 \mathrm{~mL} \mathrm{~g}^{-1} \mathrm{~h}^{-1}$. The results disclosed the formation of amorphous structure of ternary oxides with dome-top-shaped morphology which supplied abundant sites for oxygen evolution. The optical bandgap energies (1.5 and $2.05 \mathrm{eV})$ of asprepared ternary oxides were lower than their base metal oxide counterparts $(2.15-2.18 \mathrm{eV})$, which enhanced their reducibility due to easier lattice oxygen mobility. The $\mathrm{Cu}-\mathrm{Co}-\mathrm{Fe}$ ternary oxides revealed excellent performance for $\mathrm{CO}$ oxidation. The superior performance was linked to the formation of lattice and adsorbed oxygen species, synergetic effects of $\mathrm{Cu}^{2+}, \mathrm{Co}^{3+}$ and $\mathrm{Fe}^{3+}$, high reducibility and excessive oxygen mobility. The ternary oxides exhibited attractive stability and the conversion of $\mathrm{CO}$ was remained almost constant throughout the 30 hours. This work provides not only an inspiration but also attractive strategy for the development of efficient $\mathrm{Cu}-\mathrm{Co}-\mathrm{Fe}$ ternary oxides for catalytic applications.

Keywords: Cu-Co-Fe ternary oxides; Catalytic combustion; Durability; PSE-CVD; Synergetic effects.

Received 16 August 2018, Accepted 17 September 2018

DOI: $10.30919 /$ esee 8 c145

\section{Introduction}

Low temperature catalytic oxidation has been fascinated much more attention during the past decades because of high conversion efficiency, low operating temperature, eco-friendly and economical technology. ${ }^{1,2}$ Catalytic oxidation of $\mathrm{CO}$ to $\mathrm{CO}_{2}$ assumes a key part in the abatement of CO. Recently, enormous amounts of $\mathrm{CO}$ are globally released from power plants and transportation along with domestic and industrial activities. ${ }^{3}$ Low temperature catalytic oxidation of $\mathrm{CO}$ is constantly being developed as an important research topic of huge industrial interest in environmental science. ${ }^{4-6}$ The most commonly used catalysts in catalytic oxidation of $\mathrm{CO}$ are of two kinds, those built on noble metals and mixed metal oxides. Noble metals ( $\mathrm{Pd}, \mathrm{Pt}, \mathrm{Au}$, and $\mathrm{Ru}$ etc.) are used as promoter or supported as active sites on reducible oxides for instance $\mathrm{MnO}_{2}$, $\mathrm{CeO}_{2}, \mathrm{SnO}_{2}$ and $\mathrm{TiO}_{2}$ have been considered as most suitable candidates for low temperature $\mathrm{CO}$ oxidation and they are able to convert $\mathrm{CO}$ to $\mathrm{CO}_{2}$ completely at ambient temperature. ${ }^{7-9}$ However, the noble metals are very expensive due to the limited resources. ${ }^{10}$ Therefore, attentions are increasingly being focused on the design and preparation of cheap and active transition-metal based mixed

${ }^{1}$ Institute of Engineering Thermophysics, Chinese Academy of Sciences, Beijing 100190, China

${ }^{2}$ University of Chinese Academy of Sciences, Beijing 100049, China

${ }^{3}$ National Advanced School of Engineering of Maroua, University of Maroua, P.O. Box.: 46 Maroua, Cameroon

${ }^{4}$ Shanghai Research Institute of Petrochemical Technology, Shanghai 201208, China

*E-mail: tianzhenyu@iet.cn oxide catalysts as alternatives to noble metals. ${ }^{11}$

Copper and cobalt mixed oxides have been observed tremendously active and promising for oxidation of $\mathrm{CO} .{ }^{12,13}$ Over the past few years, several $\mathrm{Cu}$-Co binary oxides such as $\mathrm{CuCo}_{2} \mathrm{O}_{4}$ spinel supported on $\mathrm{Al}_{2} \mathrm{SiO}_{5},{ }^{14} \mathrm{Cu}_{0.9} \mathrm{Co}_{2.1} \mathrm{O}_{4}$ spinel on stainless steel support, ${ }^{15}$ a thin film of $\mathrm{CuO} / \mathrm{CoO}$ mixed oxides ${ }^{16}$ and $\mathrm{CuCo}_{2} \mathrm{O}_{4}$ oxide ${ }_{12}$ that dispersed on the stainless steel grid mesh (SSGM) were employed in the $\mathrm{CO}$ oxidation and exhibited very good catalytic performances. According to the reported literature, ${ }^{16}$ the existence of mixed structure of $\mathrm{Cu}$ and $\mathrm{Co}$ oxide plays a vital role in the oxidation of $\mathrm{CO}$ over $\mathrm{Cu}-\mathrm{Co}$ mixed oxides. Copper cobalt spinel presents active sites, whereas, cobalt oxide is the center of oxygen supply and transmission in $\mathrm{Cu}-\mathrm{Co}$ mixed oxides and provides active oxygen to copper-cobalt spinel for completely oxidized organic molecules. $^{17}$

Based on the above mentioned facts, it could be expected that if cobalt oxide is replaced with other metal oxides having superior oxygen storage capacity as well as oxygen-supply capacity, the catalytic activity of $\mathrm{Cu}-\mathrm{Co}$ mixed oxides in oxidation can be further promoted. Iron oxide has attractive oxygen storage capacity and also is extensively used in the oxidation reactions as a catalyst. ${ }^{18}$ Therefore, the introduction of $\mathrm{Fe}$ in the $\mathrm{Cu}-\mathrm{Co}$ mixed oxides is expected to enable the catalyst with improved oxygen capacity as well as high performance for the low temperature catalytic oxidation of $\mathrm{CO}$.

The present work aims to highlight an approach to synthesize functional thin film of Cu-Co-Fe ternary oxides using PSE-CVD route. The morphology, bulk composition, chemical composition, structure and optical properties of ternary oxides were characterized by SEM, EDS, XPS, XRD and UV-Vis spectroscopy, respectively. 
The performance of ternary oxides as catalyst, was evaluated against oxidation of $\mathrm{CO}$ in a tubular quartz flow reactor. The structural features of the ternary oxides were discussed and correlated with its performance.

\section{Experimental}

\subsection{Catalyst preparation}

The Cu-Co-Fe ternary oxides were prepared by PSE-CVD route, and details of experimental setup as well as procedure can be found in our previous works. ${ }^{19,20}$ In the present work, the precursors of copper acetylacetonate $\left(\mathrm{Cu}(\mathrm{acac})_{2}\right)$, cobalt acetylacetonate $\left(\mathrm{Co}(\mathrm{acac})_{2}\right)$ and iron acetylacetonate $\left(\mathrm{Fe}(\mathrm{acac})_{3}\right)$ were separately dissolved in ethanol. By adjusting and optimizing the molar ratios of $\mathrm{Cu}, \mathrm{Co}$ and $\mathrm{Fe}$ species: $\mathrm{Cu} / \mathrm{Co} / \mathrm{Fe}=50 / 25 / 25$, the blended feedstock was obtained, which was kept under atmospheric pressure at room temperature, in the entire deposition process. The PSE output was obtained with the opening frequency of the valve and the time at $4 \mathrm{~Hz}$ and $1.0 \mathrm{~ms}$, respectively. The blended feedstock was injected as a fine spray, into evaporation chamber at $200{ }^{\circ} \mathrm{C}$ and flow rate of $\mathrm{O}_{2}$ and $\mathrm{N}_{2}$ were 0.50 and 0.25 standard liter per minute $(\mathrm{s} / \mathrm{m})$, respectively. Bare glass (BG), stainless-steel (SS) and stainless-steel grid mesh (SSGM) substrates were used and a flat resistive heater was used to heat the substrate to $320{ }^{\circ} \mathrm{C}$, during deposition. Total pressure was kept at around $2.0 \mathrm{kPa}$ in the deposition chamber.

\subsection{Characterization}

A number of techniques were used to characterize the $\mathrm{Cu}-\mathrm{Co}-\mathrm{Fe}$ ternary oxides. Hitachi SU 8020 field-emission scanning electron microscope was used to carry out scanning electron microscopy (SEM) and energy dispersive X-ray spectroscopy (EDS). AXIS ULTRA DLD (Shimadzu Kratos) with pass energy of $80 \mathrm{eV}$ and analysis voltage of $15 \mathrm{kV}$ was used to perform X-ray photoelectron spectroscopy (XPS) for analyze the chemical compositions and ionic states of the obtained samples. The $\mathrm{C} 1 \mathrm{~s}$ peak at $284.8 \mathrm{eV}$ was used as the reference to calibrate binding energies (BE). Cary $5000 \mathrm{UV}-$ Vis-NIR spectrophotometer (range $=175-3300 \mathrm{~nm}$ ) was used to evaluate the optical properties.

\subsection{Catalytic test}

The performance of the Cu-Co-Fe ternary oxides as catalyst, was evaluated against the oxidation of $\mathrm{CO}$ in a continuous flow fixed bed quartz reactor. The setup has been described in detail somewhere else. $^{19}$ The reaction mixture containing $20 \% \mathrm{O}_{2}$ and $1 \% \mathrm{CO}$ diluted in Ar, fed into the reactor with total flow rate of $15 \mathrm{~mL} / \mathrm{min}$ and gas hourly space velocity (GHSV) of $75,000 \mathrm{~mL} \mathrm{~g}^{-1} \mathrm{~h}^{-1}$. The reactor temperature was raised with a rate of $5{ }^{\circ} \mathrm{C} / \mathrm{min}$ by means of digital electrical furnace. Moreover, the durability of $\mathrm{Cu}-\mathrm{Co}-\mathrm{Fe}$ ternary oxides was examined at $75 \%$ fuel conversion $\left(215^{\circ} \mathrm{C}\right)$ for $30 \mathrm{~h}$, under the same experimental conditions. The exhaust gas was analyzed in terms of composition with an online FTIR spectrometer (range of $400-4000 \mathrm{~cm}^{-1}$ ), associated with a homemade $\mathrm{KBr}$ transmission cell.

\section{Results and discussion}

\subsection{Morphology and bulk composition}

The surface morphology of $\mathrm{Cu}-\mathrm{Co}-\mathrm{Fe}$ ternary oxides was explored by SEM. As can be seen in Fig. 1, the as-prepared ternary oxides dispersed homogeneously on the support having dome-top-shaped geometric structures. A smooth thin film owning with loosely packed fine columnar grains was observed. Besides dome-top shapes, numerous hollows were also detected. The structure owning hollow surface may hold within more physisorbed as well as chemisorbed surface active oxygen species, which could contribute greatly in the catalytic performance. $\mathrm{Cu}-\mathrm{Co}-\mathrm{Fe}$ ternary oxides showed porous and also open structures, which could provide predisposed space impounding abundant active sites that can be beneficial for oxidation of $\mathrm{CO} .{ }^{12,16}$

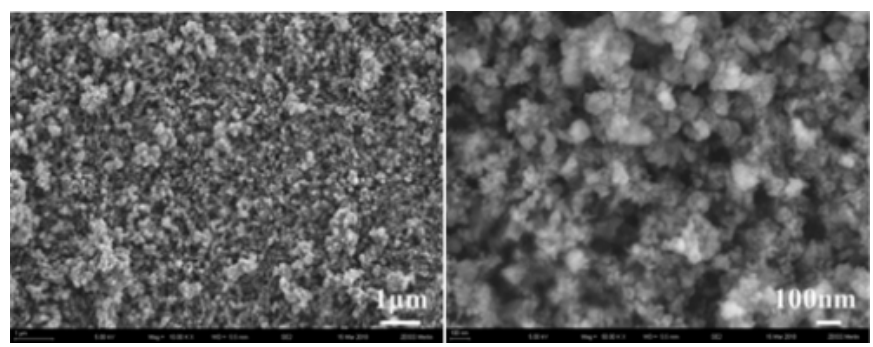

Fig. 1 SEM images of the Cu-Co-Fe ternary oxides.

The energy dispersive spectrum of the $\mathrm{Cu}-\mathrm{Co}-\mathrm{Fe}$ ternary oxides obtained from the SEM-EDS analysis clearly showed that the sample contained $\mathrm{Cu}, \mathrm{Co}, \mathrm{Fe}$ and $\mathrm{O}$ (Fig. 2). The bulk composition of $\mathrm{Cu}-$ Co-Fe ternary oxides is listed in Table 1. EDS analysis revealed the signal of $\mathrm{Cu}, \mathrm{Co}, \mathrm{Fe}$ and $\mathrm{O}$ which indicated that the metal oxide species existed on the exterior surface of inert support could act as active sites in the oxidation reaction. Therefore, it can be deduced that the $\mathrm{Cu}-\mathrm{Co}-\mathrm{Fe}$ ternary oxides with nanosize present very good textural properties that in turn could be beneficial to enhance the catalytic performance.

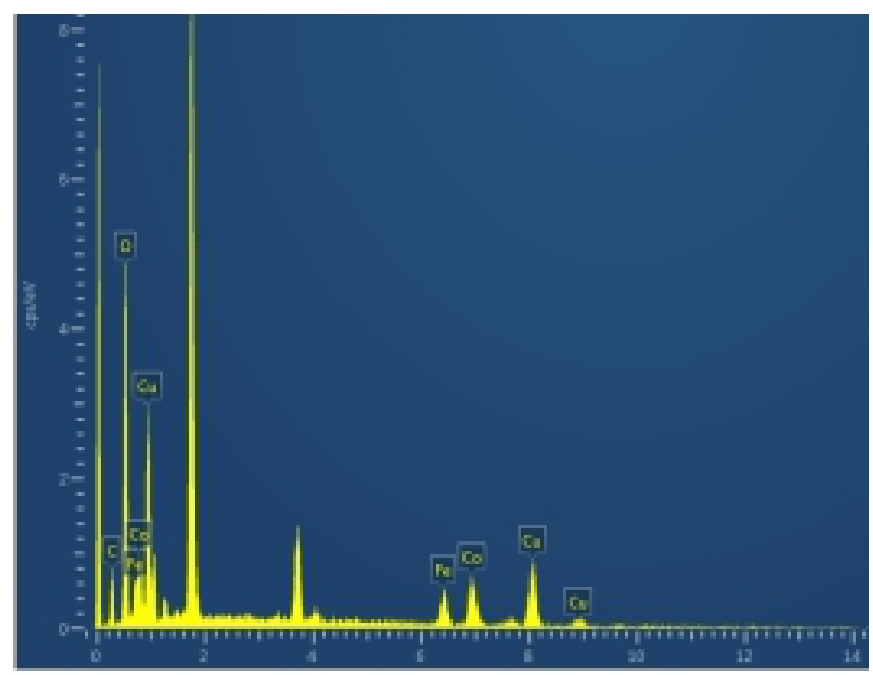

Fig. 2 EDS image of the $\mathrm{Cu}-\mathrm{Co}-\mathrm{Fe}$ ternary oxides.

\subsection{Composition and ionic state}

The surface composition and also chemical states of $\mathrm{Cu}-\mathrm{Co}-\mathrm{Fe}$ ternary oxides were studied by XPS, as shown in Fig. 3 and 4 . The $\mathrm{BE}$ for $\mathrm{Cu} 2 \mathrm{p}, \mathrm{Co} 2 \mathrm{p}, \mathrm{Fe} 2 \mathrm{p}$ and $\mathrm{O} 1 \mathrm{~s}$ as well as the atomic percentage are summarized in Table 1 . The $\mathrm{Cu}-\mathrm{Co}-\mathrm{Fe}$ ternary oxides exhibited two main peaks at 931.9 and $952.0 \mathrm{eV}$, in the $\mathrm{Cu} 2 \mathrm{p}$ spectrum that ascribed to $\mathrm{Cu} 2 \mathrm{p}_{3 / 2}$ and $\mathrm{Cu} 2 \mathrm{p}_{1 / 2}$, respectively. Satellite peaks with strong intensity were detected at higher and lower binding energy which unambiguously showed the presence of $\mathrm{Cu}^{2+}$ on the surface of the as-prepared ternary oxides. ${ }^{21}$ These species could be formed by the reaction sequence $\mathrm{Cu} \rightarrow \mathrm{Cu}_{2} \mathrm{O} \rightarrow \mathrm{CuO}$ at the surface. The Co2p 

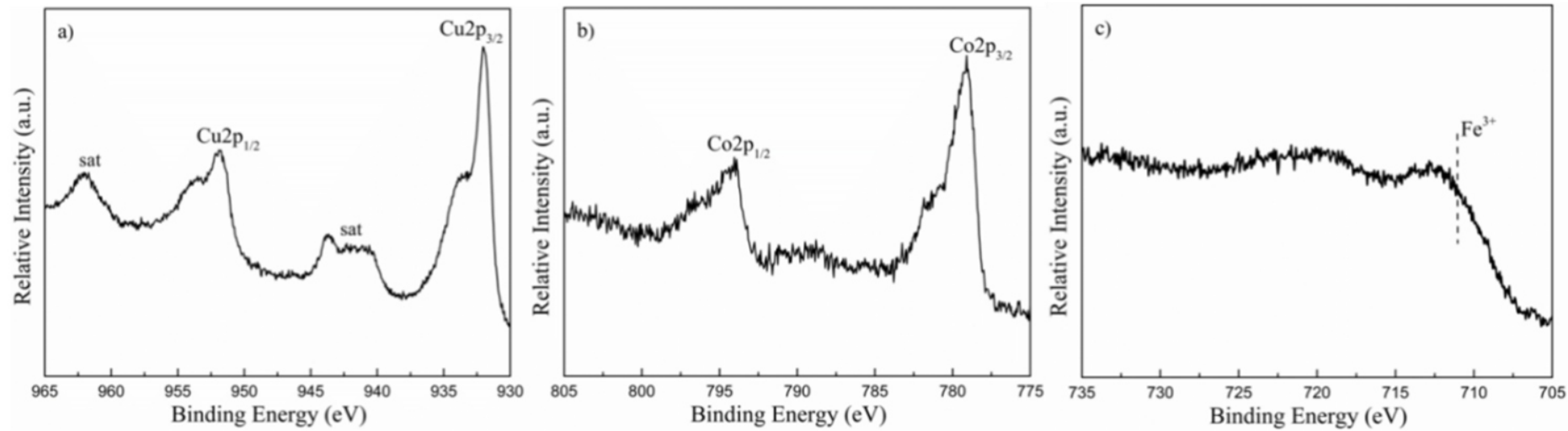

Fig. 3 XPS spectra of $\mathrm{Cu} 2 \mathrm{p}(\mathrm{a}), \mathrm{Co} 2 \mathrm{p}$ (b) and $\mathrm{Fe} 2 \mathrm{p}$ (c) of the $\mathrm{Cu}-\mathrm{Co}-\mathrm{Fe}$ ternary oxides.

spectrum of $\mathrm{Cu}-\mathrm{Co}-\mathrm{Fe}$ ternary oxides showed two main peaks at $779.1 \mathrm{eV}$ and $794.5 \mathrm{eV}$, ascribed to Co2 $\mathrm{p}_{3 / 2}$ and also Co2 $\mathrm{p}_{1 / 2}$ spinorbital peaks, respectively. As reported in the literature, ${ }^{22,23}$ the value of spin-orbit splitting for $\mathrm{Co}^{3+}$ and mixed-valance $\mathrm{Co}_{3} \mathrm{O}_{4}$ is $15.0 \mathrm{eV}$ and $15.1-15.3 \mathrm{eV}$, respectively. The value of spin-orbit splitting of $\mathrm{Co} 2 \mathrm{p}$ was found to be $\sim 15.0 \mathrm{eV}$ which showed the characteristic of $\mathrm{Co}^{3+}$. The first peak at $779.1 \mathrm{eV}$ could be assigned to $\mathrm{Co}^{3+}$, and the peak at $794.5 \mathrm{eV}$ could be attributed to $\mathrm{Co}^{3+}$. The Fe2p spectrum of $\mathrm{Cu}-\mathrm{Co}-\mathrm{Fe}$ ternary oxides showed a broad peak at $\sim 711.7 \mathrm{eV}$, which agreed well with the value for $\mathrm{Fe}_{2} \mathrm{O}_{3}$ reported in the literature. ${ }^{24}$ The satellite peak at $718.0 \mathrm{eV}$ was consistent with available literature, which also indicated that $\mathrm{Fe}$ had a $3+$ oxidation state in the ternary oxide. ${ }^{25}$ In the $\mathrm{Cu}-\mathrm{Co}-\mathrm{Fe}$ ternary oxides, the valence state of $\mathrm{Fe}$ was expected to be $3+$ if $\mathrm{Fe}$ substituted for $\mathrm{Co}$. The presence of $\mathrm{Fe}^{3+}$ ions in the ternary oxides on the surface of ternary oxides could result in availability of excess oxygen species for the oxidation reaction.

The $\mathrm{O} 1 \mathrm{~s}$ spectrum of $\mathrm{Cu}-\mathrm{Co}-\mathrm{Fe}$ ternary oxides was deconvoluted into two components as shown in Fig. 4. The peaks at $531.2 \mathrm{eV}$ and $529.6 \mathrm{eV}$ linked to adsorbed oxygen $\left(\mathrm{O}_{\mathrm{Ads}}\right)$ and lattice oxygen $\left(\mathrm{O}_{\text {Latt }}\right)$ of the ternary oxides, respectively. ${ }^{26}$ The absorbed and lattice oxygen revealed greater capability to attack an organic molecule in the region of its highest electron density owing to strong electrophilic nature and initiated the oxidation of carbon skeleton. ${ }^{27}$ Furthermore, the electrophilic oxygen species were observed to be in charge of complete $\mathrm{CO}$ oxidation $^{28}$ and the availability of excessive oxygen species was expected to be promising for oxidation of CO. The prepared ternary material could release oxygen at relatively low temperature easier than other materials counterparts (Table 2) that led to oxygen species to move from lattice to surface, which in turn could facilitate the task for $\mathrm{CO}$ to be completely oxidized when reacted with active oxygen species on surface at low temperature.

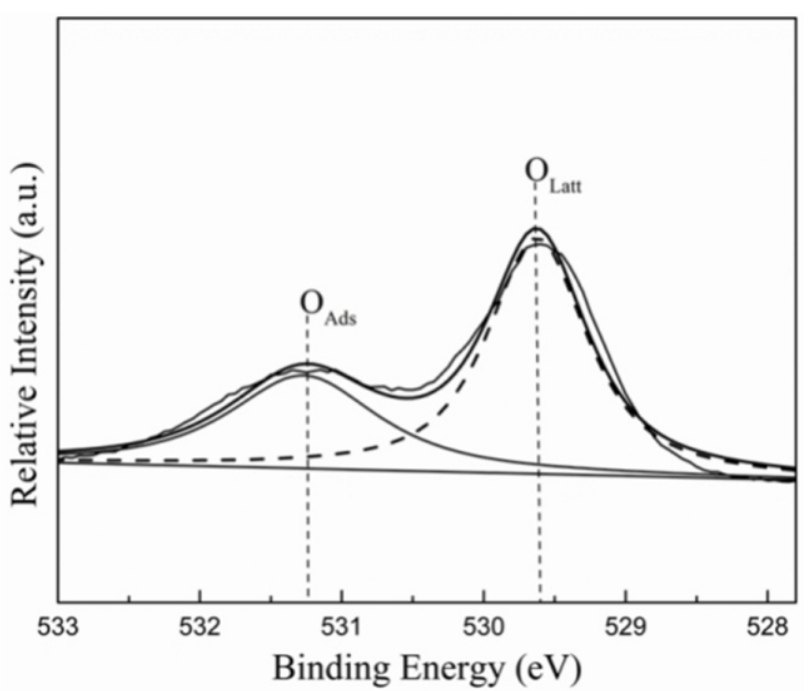

Fig. 4 XPS spectrum of $\mathrm{O} 1 \mathrm{~s}$ of the $\mathrm{Cu}-\mathrm{Co}-\mathrm{Fe}$ ternary oxides.

\subsection{Structure}

The crystalline structure and also purity of $\mathrm{Cu}-\mathrm{Co}-\mathrm{Fe}$ ternary oxides were investigated by XRD (Fig. 5). There was no characteristic peak of $\mathrm{CuO}, \mathrm{Co}_{3} \mathrm{O}_{4}$ and $\mathrm{Fe}_{2} \mathrm{O}_{3}$ phases detected in the XRD spectrum of the ternary oxides. As shown earlier by EDS and XPS results, $\mathrm{Cu}$, $\mathrm{Co}$ and $\mathrm{Fe}$ species were presented by the ternary oxides. Therefore, it revealed the amorphous structure of the $\mathrm{Cu}-\mathrm{Co}-\mathrm{Fe}$ ternary oxides. According to the literature, ${ }^{29}$ this phenomenon commonly occurred in the multicomponent and complex mixed oxides wherein energy of crystallization was found much higher than the thermal energy

Table 1 Surface and bulk composition of $\mathrm{Cu}-\mathrm{Co}-\mathrm{Fe}$ ternary oxides.

\begin{tabular}{cccccccccccccc}
\hline \multirow{2}{*}{$\mathrm{Cu} / \mathrm{Co} / \mathrm{Fe} / \mathrm{O}$} & \multicolumn{2}{c}{$\mathrm{Cu} 2 \mathrm{p}$} & \multicolumn{2}{c}{$\mathrm{Co} 2 \mathrm{p}$} & \multicolumn{2}{c}{$\mathrm{Fe} 2 \mathrm{p}$} & \multicolumn{2}{c}{$\mathrm{O} 1 \mathrm{~s}$} & \multicolumn{2}{c}{$\mathrm{Cu} / \mathrm{O}$} & $\mathrm{Co} / \mathrm{O}$ & $\mathrm{Fe} / \mathrm{O}$ & $\mathrm{O}_{\text {Latt }} / \mathrm{O}_{\text {Ads }}$ \\
& $\mathrm{BE}^{\mathrm{a}}$ & $\mathrm{At}^{\mathrm{b}}{ }^{\mathrm{b}}$ & $\mathrm{BE}$ & $\mathrm{At} \%$ & $\mathrm{BE}$ & $\mathrm{At} \%$ & $\mathrm{BE}$ & $\mathrm{At} \%$ & & & & \\
\hline Surface & 931.99 & 13.36 & 779.19 & 2.77 & 711.74 & 4.27 & 529.59 & 29.55 & 0.452 & 0.093 & 0.144 & 1.71 \\
Bulk & - & 7.80 & - & 3.67 & - & 2.44 & - & 57.78 & 0.134 & 0.063 & 0.042 & - \\
\hline
\end{tabular}

Note: ${ }^{a} \mathrm{BE}$ stands for binding energy; ${ }^{\mathrm{b}} \mathrm{At} \%$ is the relative atomic percentage. 
available at operating temperature. So, it is anticipated that synergetic effects among $\mathrm{Cu}, \mathrm{Co}$ and $\mathrm{Fe}$ species and also amorphous structure of $\mathrm{Cu}-\mathrm{Co}-\mathrm{Fe}$ ternary oxides could play vital roles in the oxidation of $\mathrm{CO}$.

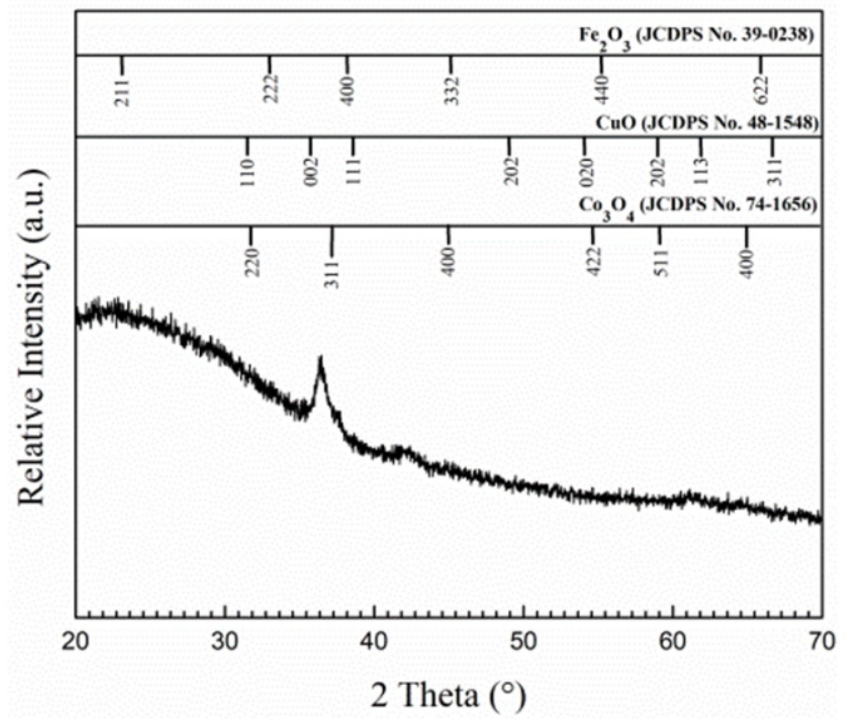

Fig. 5 XRD pattern of the $\mathrm{Cu}-\mathrm{Co}-\mathrm{Fe}$ ternary oxides.

\subsection{Optical properties}

The bandgap energy $\left(\mathrm{E}_{\mathrm{g}}\right)$ of the $\mathrm{Cu}-\mathrm{Co}-\mathrm{Fe}$ ternary oxides was evaluated by UV-vis spectroscopy. As shown in Fig. 6a, a clear absorbance was detected in the area of 350-750 nm. It was observed that the absorption progressively decreased as wavelength extended in the direction of visible region, which found in good agreement with previously reported results. ${ }^{30}$ The obtained absorption spectrum was used to assess the direct $\mathrm{E}_{\mathrm{g}}$ from the Tauc equation: $\alpha \mathrm{hv}=\mathrm{A}(\mathrm{h} v$ - $\left.\mathrm{E}_{\mathrm{g}}\right)^{\mathrm{n}}$, where hv is the photon energy, $\mathrm{E}_{\mathrm{g}}$ represents bandgap, A represents constant relying on the refractive index and $\alpha$ is the absorption coefficient. The consistent Tauc plot of hv vs $(\alpha h v)^{2}$ for the $\mathrm{Cu}-\mathrm{Co}-\mathrm{Fe}$ ternary oxides is shown in Fig. 6b. In the present study, $\mathrm{Cu}-\mathrm{Co}-\mathrm{Fe}$ oxides tended to have two bandgap energies. The bandgap energies for $\mathrm{Cu}-\mathrm{Co}-\mathrm{Fe}$ ternary oxides were obtained at 1.50 and $2.05 \pm 0.05 \mathrm{eV}$. The bandgap energies attained with $\mathrm{Cu}-\mathrm{Co}-\mathrm{Fe}$ oxide shifted to lower values as compared to corresponding values of pure copper oxide $(2.16 \mathrm{eV})$, cobalt oxide $(2.15 \mathrm{eV})$ and iron oxide
$(2.18 \mathrm{eV}){ }^{20,30,31}$ The bandgap energies $\mathrm{E}_{\mathrm{g} 1}$ and $\mathrm{E}_{\mathrm{g} 2}$ can be ascribed to $\mathrm{O}^{2-}$-octahedral ions $\left(\mathrm{Fe}^{3+} \& \mathrm{Co}^{3+}\right)$ and $\mathrm{O}^{2-}-\mathrm{Cu}^{2+}$ charge transfer, respectively. ${ }^{33}$ Moreover, numerous factors could influence $\mathrm{E}_{\mathrm{g}}$ of metal oxides for instance charged impurities, defects, disorder at the grain boundaries and etc. ${ }^{34}$ Jibril et al. ${ }^{35}$ reported a strong correlation between bandgap of the metal oxides and their catalytic behavior in oxidation reactions. The availability of excessive lattice oxygen at the surface of $\mathrm{Cu}-\mathrm{Co}-\mathrm{Fe}$ ternary oxides revealed by XPS and low $\mathrm{E}_{\mathrm{g}}$ might be determinant in the catalytic performance and play a vital part in reducibility of $\mathrm{Cu}-\mathrm{Co}-\mathrm{Fe}$ ternary oxides.

\subsection{Catalytic performance}

The catalytic performances of $\mathrm{Cu}-\mathrm{Co}-\mathrm{Fe}$ ternary oxides grown on SSGM were studied for oxidation of $\mathrm{CO}$ at atmospheric pressure. The light-off curve of $\mathrm{CO}$ conversion over $\mathrm{Cu}-\mathrm{Co}-\mathrm{Fe}$ ternary oxides is presented in Fig. 7. Remarkably, the deposition of $\mathrm{Cu}, \mathrm{Co}$ and $\mathrm{Fe}$ species on SSGM supplied suitable active sites on ternary oxide surface via synergetic effects, that boost $\mathrm{CO}$ conversion to $\mathrm{CO}_{2}$. Notably, $\mathrm{CO}$ conversion turned out to be visible at approximately $140{ }^{\circ} \mathrm{C}$ and complete $\mathrm{CO}$ conversion was attained at $234{ }^{\circ} \mathrm{C}$ over $\mathrm{Cu}-\mathrm{Co}-\mathrm{Fe}$ ternary oxides.

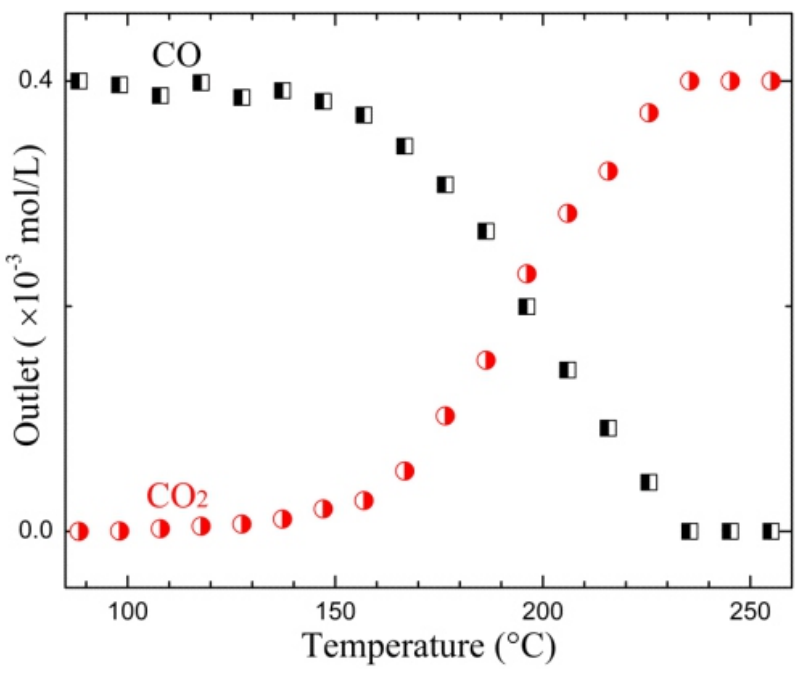

Fig. 7 Light-off curve of $\mathrm{CO}$ conversion over $\mathrm{Cu}-\mathrm{Co}-\mathrm{Fe}$ ternary oxides.
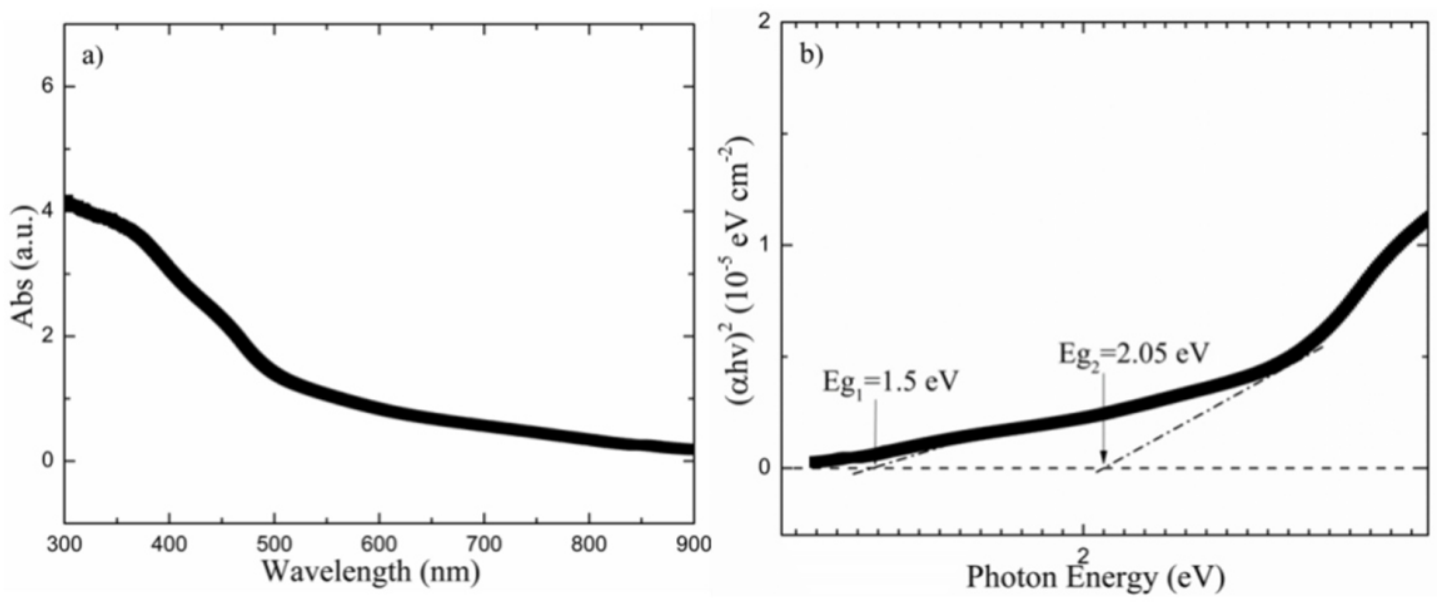

Fig. 6 UV-vis spectrum (a) and (b) (ahv) ${ }^{2}$ vs hv for the Cu-Co-Fe ternary oxides. 
Compared with the individual single metal oxides, mixed metal oxides and noble metals reported for $\mathrm{CO}$ oxidation (Table 2) in the literature, the $\mathrm{Cu}-\mathrm{Co}-\mathrm{Fe}$ ternary oxides showed better catalytic performance. Complete $\mathrm{CO}$ conversion was realized at much lower temperature about 100 to $200{ }^{\circ} \mathrm{C}$ compared to the reported metal oxide catalysts, even a high GHSV of $75,000 \mathrm{~mL} \mathrm{~g}^{-1} \mathrm{~h}^{-1}$ was used. Thus, the introduction of iron oxide in $\mathrm{Cu}-\mathrm{Co}$ mixed oxides significantly influenced the physiochemical properties of the obtained ternary oxides by providing effectual synergetic effects and improved the catalytic performance (Table 2). For CO oxidation over metal oxides, several parameters of metal oxides for example the structure, surface metal content, oxidation state of the metal species, bandgap energy and oxygen mobility could affect the catalytic performance. ${ }^{36}$ In this study, the physicochemical properties of $\mathrm{Cu}-\mathrm{Co}-\mathrm{Fe}$ ternary oxides were also correlated with the catalytic performance to gain further insights into the possible reason for high performance. In general, it is acknowledged that when oxidation reactions occurred by following the Mars-van-Krevelen mechanism, the performance of metal oxides depended on their oxygen mobility. ${ }^{37}$ The reactions involved alternative oxidation and reduction of oxides on the surface along with the formation of surface oxygen vacancies (as a fundamental step) and its replacement with oxygen in the gaseous phase. The other observation has been reported in catalytic oxidation reaction, and the abundance of oxygen adsorbed on surface of metal oxides could play a decisive role. ${ }^{38}$ It is probable that a Marsvan-Krevelen mechanism can be applied to the total oxidation of $\mathrm{CO}$ on $\mathrm{Cu}-\mathrm{Co}-\mathrm{Fe}$ ternary oxides, having lattice and absorbed oxygen as an active oxygen species. The hollow dome top-like morphology and low bandgap energy of ternary oxides could adsorb more oxygen and expose more surface area with easy oxygen mobility which probably made the oxidation occur at low temperature. ${ }^{36}$ Moreover, the synergetic effects of metal species and their reducibility played a great role in influence the redox properties and catalytic performance of $\mathrm{Cu}-\mathrm{Co}-\mathrm{Fe}$ ternary oxides for the oxidation of $\mathrm{CO} .^{39}$

Table 2 Comparison of the catalytic performances of single TMOs, mixed TMOs and noble metals.

\begin{tabular}{|c|c|c|c|c|c|c|c|}
\hline Catalyst & Materials & $\begin{array}{l}\text { Weight } \\
(\mathrm{mg})\end{array}$ & Gas Composition & $\begin{array}{l}\text { GHSV }^{a} \\
\left(\mathrm{mlg}^{-1} \mathrm{~h}^{-1}\right)\end{array}$ & $\begin{array}{l}\mathrm{T}_{50}{ }^{\mathrm{b}} \\
\left({ }^{\circ} \mathrm{C}\right)\end{array}$ & $\begin{array}{l}\mathrm{T}_{90}{ }^{\mathrm{b}} \\
\left({ }^{\circ} \mathrm{C}\right)\end{array}$ & Ref. \\
\hline \multirow{4}{*}{$\begin{array}{l}\text { Single } \\
\text { TMO }\end{array}$} & $\mathrm{Co}_{3} \mathrm{O}_{4}$ & 12 & $\begin{array}{c}1 \% \mathrm{CO} / 10 \% \mathrm{O}_{2} \\
\text { in } \mathrm{Ar}\end{array}$ & 75,000 & 335 & 350 & 39 \\
\hline & $\mathrm{CuO}$ & 20 & $\begin{array}{c}1 \% \mathrm{CO} / 10 \% \mathrm{O}_{2} \\
\text { in } \mathrm{Ar}\end{array}$ & 45,000 & 215 & 247 & 16 \\
\hline & $\mathrm{Fe}_{2} \mathrm{O}_{3}$ & 20 & $\begin{array}{c}1 \% \mathrm{CO} / 10 \% \mathrm{O}_{2} \\
\text { in } \mathrm{Ar} \\
\text { in } \mathrm{He}\end{array}$ & 45,000 & 320 & 366 & 40 \\
\hline & $\mathrm{CeO}_{2}$ & 100 & $\begin{array}{c}2 \% \mathrm{CO} / 2 \% \mathrm{Q} \\
\text { in } \mathrm{N}_{2}\end{array}$ & 60,000 & - & 374 & 41 \\
\hline \multirow{5}{*}{$\begin{array}{l}\text { Mixed } \\
\text { TMOs }\end{array}$} & $\mathrm{Cu} / \mathrm{Co} / \mathrm{Fe} / \mathrm{O}$ & 12 & $\begin{array}{c}1 \% \mathrm{CO} / 20 \% \mathrm{O}_{2} \\
\text { in } \mathrm{Ar}\end{array}$ & 75,000 & 192 & 222 & $\mathrm{TW}^{\mathrm{c}}$ \\
\hline & $\mathrm{CuO} / \mathrm{CoO}$ & 20 & $\begin{array}{c}1 \% \mathrm{CO} / 10 \% \mathrm{O}_{2} \\
\text { in } \mathrm{Ar}\end{array}$ & 45,000 & 215 & 247 & 16 \\
\hline & $\mathrm{Co}_{2.1} \mathrm{Fe}_{0.9} \mathrm{O}_{4}$ & 20 & $\begin{array}{c}1 \% \mathrm{CO} / 10 \% \mathrm{O}_{2} \\
\text { in } \mathrm{Ar}\end{array}$ & 45,000 & 260 & 300 & 42 \\
\hline & $\mathrm{Ce}_{0.80} \mathrm{Zr}_{0.12} \mathrm{Sn}_{0.08} \mathrm{O}_{2-d}$ & 300 & $\begin{array}{c}1 \% \mathrm{CO} / 5 \% \mathrm{O}_{2} \\
\text { in } \mathrm{N}_{2}\end{array}$ & 30,000 & 292 & 385 & 43 \\
\hline & $\mathrm{Ce}_{0.80} \mathrm{La}_{0.12} \mathrm{Sn}_{0.08} \mathrm{O}_{2-d}$ & 300 & $\begin{array}{c}1 \% \mathrm{CO} / 5 \% \mathrm{O}_{2} \\
\text { in } \mathrm{N}_{2}\end{array}$ & 30,000 & 266 & 349 & 43 \\
\hline \multirow{5}{*}{$\begin{array}{l}\text { Nobel } \\
\text { metals }\end{array}$} & $\mathrm{Pt} / \mathrm{Al}_{2} \mathrm{O}_{3}$ & $2 / 200$ & $\begin{array}{c}1 \% \mathrm{CO} / 1.38 \% \mathrm{O}_{2} \\
\text { in } \mathrm{N}_{2}\end{array}$ & 90,000 & 333 & 430 & 44 \\
\hline & $\mathrm{CuO}_{\mathrm{x}} / \mathrm{Nb}_{2} \mathrm{O}_{5}$ & - & $\begin{array}{c}1.5 \% \mathrm{CO} / 14.5 \% \mathrm{O}_{2} \\
\text { in } \mathrm{N}_{2}\end{array}$ & 65,000 & 155 & $\sim 185$ & 45 \\
\hline & $\mathrm{Au} / \mathrm{SiO}_{2}$ & 100 & $\begin{array}{c}1 \% \mathrm{CO} / 99 \% \\
\text { in dryair }\end{array}$ & 12,000 & 337 & 423 & 46 \\
\hline & $\mathrm{CuO}-\mathrm{TiO}_{2}$ & 2000 & $\begin{array}{c}5 \% \mathrm{CO} \text { balanced } \\
\text { with air }\end{array}$ & 15,000 & 150 & - & 47 \\
\hline & $\mathrm{Pt} / \mathrm{Pb}$ & - & - & 50,000 & - & 188 & 48 \\
\hline
\end{tabular}

Note: ${ }^{a}$ GHSV refers to the gas hourly space velocity; ${ }^{\mathrm{b}} \mathrm{T}_{50}$ and $\mathrm{T}_{90}$ correspond to the temperatures of $50 \%$ and $90 \%$ of $\mathrm{CO}$ conversion; ${ }^{\mathrm{c}} \mathrm{TW}$ stands for the results obtained in this work; TMOs stands for the transition metal oxides. 
A general review of bibliography about preferential total oxidation of $\mathrm{CO}$ over metal oxides confirmed that only a few works investigated the durability of the metal oxides. ${ }^{49}$ The deactivation of metal oxides considered as a parameter of great significance for industrial application and it recently achieved much more interests of the researcher. Therefore, the catalyst stability and effect of reaction time on the catalytic performance of $\mathrm{Cu}-\mathrm{Co}-\mathrm{Fe}$ ternary oxides were investigated by performing the $\mathrm{CO}$ oxidation reaction for $30 \mathrm{~h}$ at 215 ${ }^{\circ} \mathrm{C}$ and the obtained results are shown in Fig. 8. The results showed that the $\mathrm{Cu}-\mathrm{Co}-\mathrm{Fe}$ ternary oxides had good stability during reaction for $30 \mathrm{~h}$, without any decrease in CO conversion. The stability of $\mathrm{Cu}-\mathrm{Co}-\mathrm{Fe}$ ternary oxides was also observed better than Co-promoted $\mathrm{Pt} / \mathrm{Al}_{2} \mathrm{O}_{3}$ catalysts which reported the loss of $20 \%$ conversion in $20 \mathrm{~h}^{50}$ Therefore, the stability of $\mathrm{Cu}-\mathrm{Co}-\mathrm{Fe}$ ternary oxides could be related to the promoting effect of iron species which empowered copper and cobalt species in amorphous structure to resist against complete reduction.

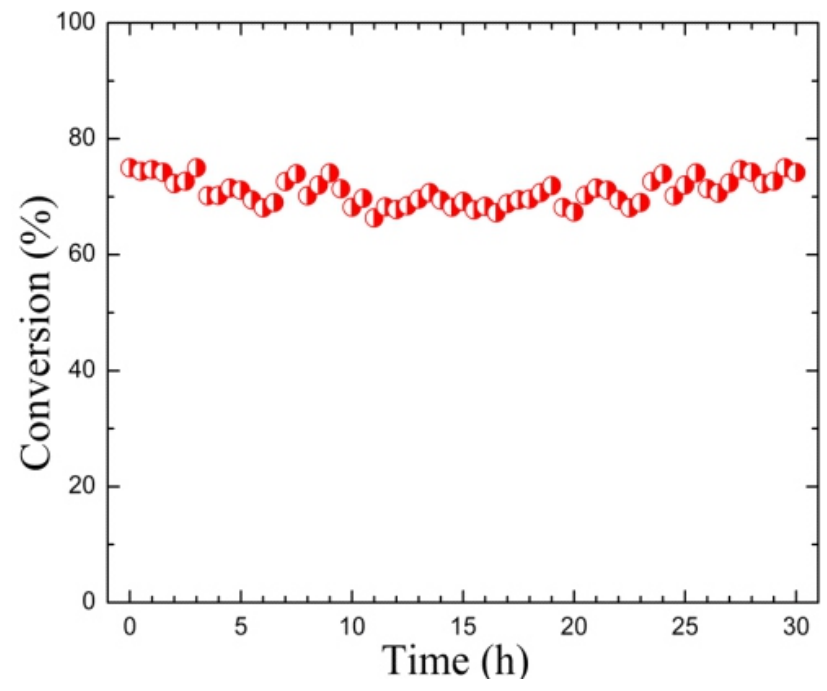

Fig. 8 Durability test of $\mathrm{Cu}-\mathrm{Co}-\mathrm{Fe}$ ternary oxides.

\section{Conclusion}

The novel introduction of $\mathrm{Fe}$ in the $\mathrm{Cu}-\mathrm{Co}$ mixed oxides was achieved by PSE-CVD method. The active sites dispersion, structure, morphology, composition, cationic rearrangement and optical bandgap energy of the $\mathrm{Cu}-\mathrm{Co}-\mathrm{Fe}$ ternary oxides were found to be quite different from the individual single or binary oxides. The catalytic performance indicated that the complete oxidation was accomplished at a much lower temperature about $100-200{ }^{\circ} \mathrm{C}$ over $\mathrm{Cu}-\mathrm{Co}-\mathrm{Fe}$ ternary oxides than other reported metal oxide catalysts and non-coated mesh. The excellent catalytic performance was attributed to the amorphous structure, hollow dome top-like morphology, cationic rearrangement of $\mathrm{Co}^{3+}, \mathrm{Cu}^{2+}$ and $\mathrm{Fe}^{3+}$, excessive availability and easy mobility of lattice and adsorbed oxygen species at the surface and lower optical bandgap energy of the $\mathrm{Cu}-\mathrm{Co}-\mathrm{Fe}$ ternary oxides, which provided the suitable active sites for the oxidation reaction. Moreover, the $\mathrm{Cu}-\mathrm{Co}-\mathrm{Fe}$ ternary oxides revealed good stability during oxidation reaction for $30 \mathrm{~h}$, without any decrease in $\mathrm{CO}$ conversion. The remarkable catalytic performance and stability of $\mathrm{Cu}-\mathrm{Co}-\mathrm{Fe}$ ternary oxides might make it possible to use as an efficient heterogeneous catalyst for the oxidation of $\mathrm{CO}$ at industrial scale. These findings open up a new avenue for a new generation of ternary oxides thin film prepared by PSE-CVD, due to energy saving, high efficiency and eco-friendly features.

\section{Acknowledgment}

ZYT thanks for the financial support from the MOST (2017YFA0402800), NSFC (No. 91541102/51476168) and Recruitment Program of Global Youth Experts. One of the authors (MW), hereby acknowledges the Chinese Academy of Sciences (CAS) and The World Academy of Sciences (TWAS) for providing with the opportunity to pursue research work under the umbrella of CAS-TWAS Presidents' Fellowship. PMK and AEK are grateful for the support of CAS (PIFI) for senior international scientists. The authors also thank Prof. Tie-Rui Zhang and Dr. Run Shi for access to the optical measurements.

\section{References}

1. K. Everaert and J. Baeyens, J. Hazard. Mater., 2004, 109, 113139.

2. R. Zhang, K. Lu, L. Zong, S. Tong, X. Wang and G. Feng, Appl. Surf. Sci., 2017, 416, 183-190.

3. I. Dincer, Renewable Sustainable Energy Rev., 2000, 4, 157-175.

4. T. Cheng, Z. Fang, Q. Hu, K. Han, X. Yang and Y. Zhang, Catal. Commun., 2007, 8, 1167-1171.

5. C. Jones, K. J. Cole, S. H. Taylor, M. J. Crudace and G. J. Hutchings, J. Mol. Catal. A: Chem., 2009, 305, 121-124.

6. J. Ayastuy, U. Iriarte-Velasco, A. Gurbani and M. GutierrezOrtiz, J. Taiwan Inst. Chem. Eng., 2017, 75, 18-28.

7. Y. Li, X. Zhang, H. He, Y. Yu, T. Yuan, Z. Tian, J. Wang and Y. Li, Appl. Catal., B, 2009, 89, 659-664.

8. S. Ivanova, C. Petit and V. Pitchon, Gold Bull., 2006, 39, 3-8.

9. H. Liu, Y. Lin and Z. Ma, J. Taiwan Inst. Chem. Eng., 2016, 62, 275-282.

10. B. Zhao, C. Yang, Q. Wang, G. Li and R. Zhou, J. Alloys Compd., 2010, 494, 340-346.

11. Z. Y. Tian, P. H. T. Ngamou, V. Vannier, K. Kohse-Höinghaus and N. Bahlawane, Appl. Catal., B, 2012, 117, 125-134.

12. Z. Y. Tian, H. Vieker, P. M. Kouotou and A. Beyer, Faraday Discuss., 2015, 177, 249-262.

13. Z. Li, H. Wang, X. Wu, Q. Ye, X. Xu, B. Li and F. Wang, Appl. Surf. Sci., 2017, 403, 335-341.

14. D. Stoyanova, M. Christova, P. Dimitrova, J. Marinova, N. Kasabova and D. Panayotov, Appl. Catal., B, 1998, 17, 233-244.

15. P. Stefanov, I. Avramova, D. Stoichev, N. Radic, B. Grbic and T. Marinova, Appl. Surf. Sci., 2005, 245, 65-72.

16. S. B. Fan, P. M. Kouotou, J.J. Weng, G.F. Pan and Z.Y. Tian, Proc. Combust. Inst., 2017, 36, 4375-4382.

17. J. Motuzas and J. C. D. da Costa, J. Mater. Chem. A, 2015, 3, 17344-17350.

18. C. Dueso, C. Thompson and I. Metcalfe, Appl. Energy, 2015, 157, 382-390.

19. G. F. Pan, S.B. Fan, J. Liang, Y.X. Liu and Z.Y. Tian, RSC $A d v$. 2015, 5, 42477-42481.

20. A. El Kasmi, Z.Y. Tian, H. Vieker, A. Beyer and T. Chafik, Appl. Catal., B, 2016, 186, 10-18.

21. L. Dong, L. Zhang, C. Sun, W. Yu, J. Zhu, L. Liu, B. Liu, Y. Hu, F. Gao and L. Dong, ACS Catal., 2011, 1, 468-480.

22. J. Cheng, J. Yu, X. Wang, L. Li, J. Li and Z. Hao, Energy Fuels, 2008, 22, 2131-2137.

23. J. Y. Luo, M. Meng, X. Li, X. G. Li, Y. Q. Zha, T. D. Hu, Y. N. Xie and J. Zhang, J. Catal., 2008, 254, 310-324.

24. T. Yamashita and P. Hayes, Appl. Surf. Sci., 2008, 254, 24412449.

25. A. Gupta, A. Kumar, U. V. Waghmare and M. Hegde, Chem. 
Mater., 2009, 21, 4880-4891.

26. Q. Liu, L.C. Wang, M. Chen, Y. Cao, H.Y. He and K.N. Fan, J. Catal., 2009, 263, 104-113.

27. P. Li, D. E. Miser, S. Rabiei, R. T. Yadav and M. R. Hajaligol, Appl. Catal., B, 2003, 43, 151-162.

28. L. F. Liotta, H. Wu, G. Pantaleo and A. M. Venezia, Catal. Sci. Technol., 2013, 3, 3085-3102.

29. K. Saji and M. Jayaraj, Thin Solid Films, 2008, 516, 6002-6007.

30. S. S. Fareed, N. Mythili, H. M. Mohaideen, K. Saravanakumar, R. Chandramohan and G. Ravi, J. Mater. Sci. - Mater. Electron., 2016, 27, 3420-3426.

31. N. Bahlawane, E. F. Rivera, K. Kohse-Höinghaus, A. Brechling and U. Kleineberg, Appl. Catal., B, 2004, 53, 245-255.

32. M. Al-Kuhaili, M. Saleem and S. Durrani, J. Alloys Compd., 2012, 521, 178-182.

33. Z. Y. Tian, N. Bahlawane, V. Vannier and K. Kohse-Höinghaus, Proc. Combust. Inst., 2013, 34, 2261-2268.

34. A. Bielański and J. Haber, Catal. Rev. Sci. Eng., 1979, 19, 1-41.

35. B. Y. Jibril, React. Kinet. Catal. Lett., 2005, 86, 171-177.

36. Z. Zhu, G. Lu, Z. Zhang, Y. Guo, Y. Guo and Y. Wang, ACS Catal., 2013, 3, 1154-1164.

37. H. Lee, J. C. Jung, H. Kim, Y.M. Chung, T. J. Kim, S. J. Lee, S.H. Oh, Y. S. Kim and I. K. Song, Catal. Lett., 2009, 131, 344349.

38. S. Veleva and F. Trifiro, React. Kinet. Catal. Lett., 1976, 4, 1924.

39. P. M. Kouotou, Z.Y. Tian, U. Mundloch, N. Bahlawane and K.
Kohse-Höinghaus, RSC Adv., 2012, 2, 10809-10812.

40. P. M. Kouotou, Z.Y. Tian, H. Vieker and K. Kohse-Höinghaus, Surf. Coat. Technol., 2013, 230, 59-65.

41. P. A. Deshpande, S. Aruna and G. Madras, Catal. Sci. Technol., 2011, 1, 1683-1691.

42. P. M. Kouotou, H. Vieker, Z.Y. Tian, P. T. Ngamou, A. El Kasmi, A. Beyer, A. Gölzhäuser and K. Kohse-Höinghaus, Catal. Sci. Technol., 2014, 4, 3359-3367.

43. D. Devaiah, T. Tsuzuki, T. Boningari, P. G. Smirniotis and B. M. Reddy, RSC Adv., 2015, 5, 30275-30285.

44. A. Törncrona, M. Skoglundh, P. Thormählen, E. Fridell and E. Jobson, Appl. Catal., B, 1997, 14, 131-145.

45. E. Leung, A. Shimizu, K. Barmak and R. Farrauto, Catal. Commun., 2017, 97, 42-46.

46. K. Qian, W. Huang, Z. Jiang and H. Sun, J. Catal., 2007, 248, 137-141.

47. S. Dehestaniathar, M. Khajelakzay, M. Ramezani-Farani and H. Ijadpanah-Saravi, J. Taiwan Inst. Chem. Eng., 2016, 58, 252258.

48. S. B. Kang, M. Hazlett, V. Balakotaiah, C. Kalamaras and W. Epling, Appl. Catal., B, 2018, 223, 67-75.

49. N. Bion, F. Epron, M. Moreno, F. Marino and D. Duprez, Top. Catal., 2008, 51, 76.

50. N. E. Nuñez, H. P. Bideberripe, M. Mizrahi, J. M. RamalloLópez, M. L. Casella and G. J. Siri, Int. J. Hydrogen Energy, 2016, 41, 19005-19013. 